\title{
Wild American Savages and the Civilized English: Catlin's Indian Gallery and the Shows of London
}

Robert M. Lewis

\section{(2) OpenEdition \\ Journals}

Electronic version

URL: https://journals.openedition.org/ejas/2263

DOI: $10.4000 /$ ejas. 2263

ISSN: 1991-9336

Publisher

European Association for American Studies

\section{Electronic reference}

Robert M. Lewis, "Wild American Savages and the Civilized English: Catlin's Indian Gallery and the Shows of London", European journal of American studies [Online], 3-1 | 2008, document 6, Online since 02 June 2008, connection on 08 July 2021. URL: http://journals.openedition.org/ejas/2263 ; DOl: https://doi.org/10.4000/ejas.2263

This text was automatically generated on 8 July 2021.

Creative Commons License 


\title{
Wild American Savages and the Civilized English: Catlin's Indian Gallery and the Shows of London
}

\author{
Robert M. Lewis
}

\section{Introduction: Authenticity and Artifice}

1 George Catlin was the outstanding painter of nineteenth-century American Indian life, and a flamboyant showman. Brian Dippie has shown that the two roles were intimately connected. ${ }^{1}$ Catlin had a grand design to record "doomed" Indian cultures for posterity. "I have flown to the rescue of their looks and their modes," he pronounced from London in 1841. White settlers were exterminating them, "yet, phoenix-like, they may rise from 'the stain of the painter's palette,' and live again upon canvass, and stand forth for centuries to come, the living monuments of a noble race." ${ }^{2}$ To this end, he persevered with his field research: he devoted half-a-dozen years in the 1830 s to sketching and painting "wild" "red men" in the Great Plains, and spent several more in South America in the 1850s. He was scrupulous in recording the customs unique to the Plains tribes. In his Gallery catalogue, he certified that "every painting has been made from nature, BY MY OWN HAND," and showed "true and fac-simile traces of individual life and historical facts." He took pains to establish his credentials as a true witness; to verify his claims, he quoted pages of testimonials from the great and the good associated with the Indian question and displayed their signatures to authenticate his illustrations. ${ }^{3}$ His purpose, as he repeated many times, was to "impart useful instruction to those who are curious to learn the true character of the Indians." ${ }^{4}$

2 For the remainder of his long life, he finished portraits and landscapes in the studio, produced numerous copies for sale, and decade after decade, lobbied Congress and appealed to wealthy benefactors for assistance. But when patronage failed to meet his pressing financial needs, he resorted to exhibitions that combined authentic artefacts with dramatic re-enactments; his publications numbered both elaborately hand- 
colored portfolios for wealthy connoisseurs and volumes that mixed good-quality pictorial illustrations and ethnographical description with humorous anecdote and autobiographical narrative.

Rosemarie Bank has argued that nineteenth-century museums had no scrupulous demarcation between fact and fiction, and commonly exercised embellishment of fact by invention or exaggeration or stagecraft. In Philadelphia, in the early republic's most esteemed museum, Charles Willson Peale intended to transform the traditional cabinet of amusing curiosities into a reputable institution promoting rational and scientific knowledge. Nevertheless, financial pressures and his sons' persuasiveness led him to sacrifice strict classification for some crowd-pleasing spectacles, with scientific novelties and dinosaur bones interspersed with fat boys and waxwork horrors. Catlin had visited Peale's emporium and was aware of the competitive challenge of rival Indian galleries. Some dramatic entertainment to enhance educational objectives was in keeping with normative expectations of museums in America at that time. ${ }^{5}$

The tension between idealism and opportunism that was a persistent strain in Catlin's character became more pronounced during the promotion of his Indian Gallery in London from 1840 to 1845. Exhibiting his art in England had been one of his long-term aims, but only if his goal of finding patronage within the United States foundered. In 1829 he wrote to the Secretary of War seeking a federal government post on the Upper Missouri to pursue the "ultimate object of my ambition" for "historical painting" among the "savage Indians" who were "the finest models in Nature, unmasked and moving in all their grace and beauty." If granted funding and access to frontier locations, in only two years, he assured Peter Porter, "I could return with a collection of portraits of dignified chiefs of different nations and painting respecting all their different manners, costumes, as would enable me to open such a gallery here in this country and there in London as would in all probability handsomely pay me for all of my laboring, and afford me in the advantages of a successful introduction across the Atlantic." Disappointed, he nevertheless devoted the next decade to depicting the tribes scattered beyond the Mississippi Valley and promoting his collection by lecturing and arranging exhibitions in the major Midwestern and Northeastern cities. The broadside advertising his show in Washington in April 1838 promised landscape views of the "uncivilized regions" of the "Prairies of the "Far West," but notably, "a representation of the wildest tribes of Indians in America, and entirely in their Native Habits and Costumes," "all of whom he had been among, and Painted his portraits from life." However, his annual tours from 1833-39 were a critical rather than a financial success. Finally, when Congress stalled again on purchasing his collection, he resolved to carry out his threat and take his treasure abroad. Philanthropist and former mayor Philip Hone who admired the exhibitions in New York in 1837 and again in 1839 noted with regret the artist's departure for England in late November: "Mr. Catlin, the Indian traveler, ... will shew the greatest and most interesting collection of the raw material of America that has ever been on this side of the water."

5 Catlin arrived in London in January 1840. In smart Piccadilly he leased the largest room within the Egyptian Hall. There, in the capital's premier exhibition showplace, in the hundred-foot-long arena, he unpacked his eight tons of freight, and arranged his Indian Gallery around the centerpiece, the twenty-five foot-high Crow wigwam of twenty buffalo hides. On the walls were three hundred portraits of the Plains tribes. Trophies of hunting and gathering-bear-claw necklaces, shells, beads, eagle plumes, 
and animal skins-and the occasional silver medal or gold coin, adorned the bare upper-body torsos of the men. Two hundred other paintings illustrated buffalo hunts, dances, and religious ceremonies, and landscapes of the vast and empty treeless prairie. There were several thousand artefacts-tobacco pipes and domestic objects, but especially weapons of war, the tomahawks, scalping knives, and clubs-but the two live grizzly bears he brought proved too troublesome for the exhibition. The rich red and brown shades, the contrasting textures of fur and feather, the tattoos and paint decorations, made the collection as colorful as any group of European military dress uniforms or aristocratic finery. Catlin's Indian Gallery matched any show from Africa or Asia, and was as varied as many a trade exhibition celebrating the industrial prowess of European nations.

6 However, Catlin soon learned that art alone would be an insufficient inducement for the English to visit the Gallery. Invited to a preview of the exhibition, the Times reporter praised Catlin as the best informed guide to American Indian customs, but found the innumerable artefacts merely "curious" and "of secondary importance." What interested the newspaper far more was why American savages inflicted the "most abhorrent and execrable cruelties" beyond the comprehension of civilized observers, both on their enemies and in ceremonies initiating their own young men into manhood. The paintings, the Times declared, offered "a vast field for the researches of the antiquary, the naturalist, and the philosopher," but not, by implication, much enjoyment for the general visitor. ${ }^{9}$ Authentic art needed explanation or narrative-or artifice and dramatic interpretation. For the English were fascinated by the "Indian" as American and "savage," as the counter-image of British civilized culture. Theater, perhaps more than art, served that purpose. Catlin duly responded.

\section{The Shows of London and British Attitudes towards Americans}

7 Because he realized the Indian Gallery faced very serious competition, Catlin advertised extensively in the capital's major newspapers and weekly periodicals. London, he wrote to his father, "is filled with Ex[hibitio]ns. \& places of amusement in proportion to the number of its inhabitants, and all strive \& struggle for their proportion of visitors, who seem divided and drawn so many ways." ${ }^{10}$ The range of shows was extraordinary. High culture was hardly dominant, although the British Museum and the National Gallery offered free admission. There was little serious drama for the population of nearly two million. There were elaborate spectacles on huge stages at Drury Lane and Covent Garden, and outdoors at Vauxhall Gardens, Cremone Gardens and the Surrey Gardens. Deregulation of the theater in 1843 legitimized earlier speculative enterprises. Cheap variety entertainment in penny gaffs and public-house backrooms competed with traditional amusements at Bartholomew Fair and Greenwich Fair. Madame Tussauds' Chamber of Horrors was the most sensational of the many waxwork displays. In hired rooms there were fly-by-night peepshows of living skeletons, giants and dwarfs, bearded ladies, and mechanical marvels. Ethnographical exhibitions abounded Hottentots, Kaffirs, Chinese, Maoris, South Sea Islanders, and "Aztec Lilliputians." For the poorest, there were the travelling street shows of Punch and Judy, and the musicians and magicians that Henry Mayhew described at length years later in London Labour and the Labouring Poor. ${ }^{11}$ 
8 Plenty of American showmen proved their worth in this intensely commercial business. America was in vogue. Blackface minstrels had been popular in London since the first performance of "Jim Crow" Rice in the early 1830s, but the Virginia Minstrels troupe in 1843 created a sensation. Soon, minstrel songs had Cockney accents. The St. James Theatre specialized in Ethiopian Serenaders, and aristocracy and middle classes delighted in American "darkey" musical comedy. ${ }^{12}$ Then P. T. Barnum, the shrewd, publicity-seeking proprietor of New York's American Museum, took the capital by storm. From 1844 to 1846, "General" Tom Thumb, Barnum's man-midget, charmed all with his witty impersonations of classical and contemporary personalities, and his renditions of "Yankee Doodle." Barnum also attempted to profit from Londoners' curiosity about the mysterious American frontier, but his hoaxed "What Is It?" or "The

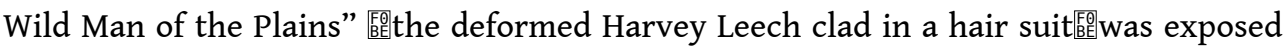
in August $1846 .{ }^{13}$ Huge American moving panorama paintings were spectacles of wonder. The "American Exhibition" of views of New York City in High Holborn in 1843 was soon eclipsed by grandiose multi-media performances, when John Banvard and John Rowson Smith offered rival pictorial surveys of travel along the Mississippi river and western frontier in 1849. Banvard's lectures and musical accompaniment, his "Jonathanisms and jokes, poetry and patter," one reviewer wrote, were as entertaining as his "three-mile" painting. ${ }^{14}$ Hiram Powers's exhibition of his marble statue of the sensational "Greek Slave" at the Crystal Palace in 1851 epitomised the American presence in London.

9 America intrigued the English public in 1840. Diplomatic tensions remained after the War of 1812, and disputes over Texas, Oregon, and the Canadian border continued to sour relations. The commercial and territorial expansion of the United States made it of particular significance to the English. It was the chief rival in shipping and American cotton exports were vital for North English factories. There were grumbles about protective tariffs, about American banks and the repudiation of commercial debts. Travel-writing was a very popular genre, and the United States was a favorite subject: three hundred accounts were published in the generation before the Civil War. One of the most controversial, Frances Trollope's Domestic Manners of the Americans (1832), appeared in four editions within a year. Visitors commented on transatlantic differences-on slavery in the South, on the new cities of the Atlantic coast, on government and politics, on rude manners and crude customs, and inevitably, on the frontier west, with its new settlements, new land, and new people..$^{15}$

10 Canada had been the destination favored by British emigrants, but by the late $1830 \mathrm{~s}$ its powerful neighbor attracted much greater numbers. Emigration to North America increased from fewer than a hundred thousand in the 1820 s to well over a million in the 1840s, eight hundred thousand of them going from Britain to the United States. Newspaper advertisements and a flood of cheap emigrants' guides informed agricultural laborers jobless through enclosure, or craftsmen made redundant by factories and mechanization, of high wages and abundant good land available at low prices across the Atlantic. ${ }^{16}$ Most manuals were supremely optimistic about prospects in the United States. Thus Calvin Colton praised it as an "open field" with abundant resources, and "destined" to "ultimately arrive at the perfection of the constitution of human society." 17

11 America's political system was at the center of debates. In the British periodical press before and after the Great Reform Bill of 1832, expansion of the suffrage in the 
American states was often cited as the salient example or counter-example. "More powerful than the eloquence of Mirabeau or the sword of Napoleon, the democratic government of America has struck far and wide into the minds of the European people," the Tory Archibald Alison warned in 1833. Alison feared revolutionary contagion from "mobocracy," and attacks upon aristocratic privilege. ${ }^{18}$ For liberals like John Stuart Mill, Alexis de Tocqueville's Democracy in America charted radical developments in liberty and equality. America also pricked the consciences of humanitarians like Mill. The emancipation of the slaves in the British West Indies in 1833 drew attention to the United States as one of the few remaining slaveholding countries. In abolitionism, as in other areas of reform-evangelical revivalism, temperance, peace, education, utopian socialism, the care of the deprived and the depraved-there was a transatlantic dialogue of ideas and idealists. ${ }^{19}$ The Illustrated London News lectured Americans on "the code of social morality" and segregation as "the evil that pervades the whole of the States." The most notorious custom of the nation was the "distinction between the black and white races, so strictly kept." "In England we know nothing of this," it added coyly. ${ }^{20}$

The English had begun to recognize distinctively American themes in literature and drama. In the 1820s, Washington Irving and James Fenimore Cooper were the first American authors to be read widely in England. Cooper was acclaimed for his adventure stories generally, and not merely of the frontier. Many of his novels were adapted for the stage, and The Pilot, dramatized by Edward Fitzball, had a run of more than a hundred performances. ${ }^{21}$ The theater explored the American national character, notably in the 1824 one-man show, At Home with Charles Mathews. Mathews told his London audience that before he toured the United States in 1822-23, he too believed Americans were squatters, "all dresst in furs, feathers, and tomahawks," spitting and chewing tobacco. For three and a half hours, he gave impressions of blacks slave and free, immigrants Irish and French, Jonathan the Yankee and the Kentucky frontiersman. "I reckon" and "I guess" sprinkled liberally made American speech distinctive. Mathews, one newspaper noted, "has introduced upon the stage of this country the peculiarities of manner and accent, which characterize that remote, but important nation." The simultaneous appearance in London theatres in 1836 of the blackfaced Thomas "Jim Crow" Rice, the dramatic actor Edward Forrest, and George "Yankee" Hill affirmed distinctive attributes of the brash American..$^{22}$ By the 1840s, English magazines like Punch pictured "Brother Jonathan" as brash, insolent, roughmannered, lounging in a chair tilted back, with a pistol in his belt, smoking a cigar, eager for the latest speculative venture.

All that was missing was the Indian. Fitzball, the dramatist most notorious for scenes of Gothic horror, produced Oconesto or The Mohawk Chief at the Royal Pavilion Theatre on September 3 1838. One reviewer described it as a bloodthirsty tale of "savages, tomahawks and scalping knives." ${ }^{33}$ Dressing up as an Indian was an exotic imaginary for actors. The playwright Colley Grattan recalled meeting the alcoholic and probably deranged Edmund Kean in preparation for his leading role in Grattan's play, Ben Nazir the Saracen. For the most acclaimed actor of his era, performing the American Indian was the key to another world-even the Orient. During his North American tour, Kean fled to Quebec and had been initiated as a Huron chief, renamed Alanienonideh, in 1826. In 1827 Grattan found Kean at home rehearsing and conditioning himself psychologically for performing the Turk on stage. "He was sitting up in his bed," Grattan wrote six years later, "a buffalo skin wrapped round him, a huge hairy cape, 
decked with many coloured feathers, on his head, a scalping knife in his belt and tomahawk in his hand. He was making up his face for a very savage look." 24

It was an age in awe of extravagant individuals, and Kean embraced it. Newspapers had followed avidly the adventures of the Tahitian Omai introduced by Captain James Cook, and Tipu Sultan , the Sultan of Mysore. Popular drama made a fetish of exotic animals and exotic individuals. ${ }^{25}$ News of Catlin's venture, announced in advance by the Athenaeum, the capital's leading literary magazine, intrigued London's articulate classes. The coming exhibition would be both "savage" and American.

\section{Unveiling the New Man of the New World in Old England}

North American Indians had been displayed in England even before the arrival of Pocahontas in 1616. Originally, the interest had been in the "Wild Man" of medieval legend, a mythical naked and hairy child of nature, half-man, half-monster, with prodigious and beastly appetites. The aboriginal inhabitants of the New World hardly conformed to that stereotype, although suspicions of cannibalism lingered. Crowds gathered to gawp at the rare Eskimo or woodlands primitive in a travelling fair or town sideshow. ${ }^{26}$ During the long controversy over taxation and political representation before the Revolution, the Indian became the symbol of a separate American identity, most noticeably when colonists disguised as Mohawks dumped the king's tea in Boston harbor in 1773. Sixty-five political prints issued in England between 1765 and 1783 by friends and foes of the rebel cause depicted America as an Indian, usually at the mercy of cruel exploiters. ${ }^{27}$

The Indian became a significant subject in the British imagination in the late eighteenth and early nineteenth centuries, especially in literature. The Romantic poets -Wordsworth, Coleridge, Southey, and Felicia Hemans-depicted fictional Indians as free spirits, noble savages endowed with a natural spirituality and living in harmony with their environment. ${ }^{28}$ No one was more influential than Sir Walter Scott who saw parallels between the picturesque aborigines of the forests and the Picts and Highlanders of old Scotland. ${ }^{29}$ He praised Fenimore Cooper as "my friend." "We sympathize with his Indian chiefs and back-woodsmen," he wrote in 1833, "and acknowledge, in the characters which he presents to us, the same truth of human nature by which we should feel ourselves influenced if placed in the same condition." ${ }^{30}$ At Abbotsford, his faux-medieval castle near Melrose, Scott displayed a Creek tomahawk and a Mohawk quiver as trophies of a brave race on the verge of extinction at the hands of debased white settlers. ${ }^{31}$ Interest in the Indian as a subject in art waned after the Revolution but the sentimental images of the disappearing native, notably by Joseph Wright of Derby, set a nostalgic tone of loss. ${ }^{32}$

17 Popular literature offered conflicting narratives, often less benign than Romantic fiction. A True History of the Captivity and Restoration of Mrs. Mary Rowlandson had been well known since its first publication in 1682, and the new editions of the 1770 s emphasized atrocity, with illustrations of the brave Amazon resisting her captors. The best-selling captivity tale of the nineteenth century was very different in style and content from Rowlandson's story of Puritan faith tested. James E. Seaver's A Narrative of the Life of Mrs. Mary Jemison, issued locally in New York state in 1824 but soon followed 
by two English editions, did not neglect tales of brutal warfare. But Jemison told of a British immigrant taken by force, widowed and re-married, of her domestic life as a Seneca "squaw" and troubles with her eight "Indian" children, and finally, how she was robbed of her landed inheritance by an unscrupulous white man pretending to be her kin. Seaver depicted his eighty-year-old interviewee as almost completely Indianized, with very halting English and few civilized customs. "Her habits are those of the Indians-she sleeps on skins without a bedstead, sits upon the floor or a bench, holds her victuals on her lap, or in her hands. . . The doctrines taught in the Christian religion, she is a stranger to." Jemison's narrative posed a fascinating psychological puzzle for English readers: why did the teenage captive forsake her English nurture and choose to remain with the fierce Seneca for the rest of her long life, when she had opportunities to escape? ${ }^{33}$ John Dunn Hunter's well-publicized account of his early years among the Kansas and Osage also aroused the curiosity of those raised on traditional bloodthirsty tales. For the most part, Hunter praised the generosity of "this neglected, persecuted, and much injured portion of the human family," but predicted its demise when confronted by greedy and unscrupulous settlers. To the English, he was a fantasy figure-in Felicia Hemans' poem, "A Child of the Forests," of "free and boundless woods"-with a plan to civilize and save the dying Indian. ${ }^{34}$

It was Charles Augustus Murray who provided the assistance essential for Catlin's early success in London. Murray was Scottish, educated at Eton and Oxford, a noted classical scholar who had met Goethe, Walter Scott and Fenimore Cooper. As the grandson of Lord Dunsmore, the last British governor of Virginia in 1775, he had a family claim in matters American. He spent more than two years travelling in the United States in 1834-36, lived for a summer among the Pawnee near St. Louis, and had met Catlin on a Missouri River steamboat in 1835. His lengthy travel book published in 1839 established his reputation as a British authority on America and on the Plains Indians. ${ }^{35}$ Murray's services to Catlin were vital. He booked the Egyptian Hall before the American arrived; he solicited dinner invitations with high-ranking nobility, and appointments with artists and literary figures, with editors of newspapers and magazines, and with likely patrons; he had Catlin invited as a speaker at dinners in select circles, including the Royal Highland Society, and at two prestigious scientific bodies, the Royal Institution and the Royal Geographical Society; as Master of the Queen's Household, he arranged three audiences with Queen Victoria; he contacted likely subscribers and organized the list for private publication of Catlin's Notes and Letters in October 1841. Thanks to Murray, Catlin boasted, he was greeted with "a cheering flood of soul and intellect," and gained entry to "the recessed world of luxury, refinement, and comforts of London, which not even the imagination of those who merely stroll through the streets can by any possibility reach." ${ }^{36}$

\section{Playing Indian in Public and Private}

19 It was perhaps also Murray who encouraged Catlin's showmanship. In between his duties at Buckingham Palace and Windsor Castle, Murray was, Catlin reported, "constantly present," "almost daily," at the Egyptian Hall. He escorted dukes and duchesses and conducted private tours of the Gallery, pointing out items of particular interest, especially those with personal associations. He paused before Catlin's portrait of Wee-ta-ra-sha-ro, and explained that the Wichita had saved him from the Pawnee 
five years earlier. However, the paintings were merely a backcloth for a dramatic performance that lent color to mere canvas. Murray enlivened interpretations of Indian customs with personal anecdotes of his western experiences. "He took also in his hands," Catlin wrote, "their war-clubs, their tomahawks and scalping knives, and then the scalps from the heads of enemies slain in battle, and ably explained them all. With these he made lasting and thrilling impressions." ${ }^{37}$

Catlin added theater to art. He needed little encouragement: dramatic illustration was an intrinsic part of his style. In his lecture to London's prestigious Royal Institution in February 1840, he outlined his grand design, a Museum of Mankind that would preserve "the looks and manners and history of all the declining and vanishing races of man." Zoos and natural history museums were collecting the world's flora and fauna and representative geological specimens, but that task might still be left to later centuries. Far more urgent was the "war of extermination" in process between the aggressive "civilized" conquerors and "native tribes" that was leading to the complete destruction of their cultures. As he reminded his audience, at the present time the British were expanding in more than thirty colonies worldwide, and economic modernization brought calamity-usually unintentionally-to the aboriginal populations. Catlin's plan was that artists and scientists might collect information before the inevitable loss of all information; his own collection "would ultimately form the basis of such an institution." It was an ambitious-and self-serving-scheme to which he alluded on many occasions for the rest of his life, especially when justifying his claims for patronage. It was characteristic of Catlin that when he lectured to England's leading intellectuals on a subject with which he was passionately engaged, he illustrated his talk not only with paintings set on an easel but with "several living figures, dressed in Indian costumes, with weapons in hand." 38 Perhaps the audience applause and what Catlin claimed was unanimous approval suggested that English intellectuals in the Victorian age also thought that the use of faux-Indians as dramatic props was not improper.

21 In America, Catlin had spiced his Gallery lectures by appearing in 1838 in the extravagant costume of a Blackfoot medicine man, with an all-encompassing bear skin draped over his body and a surfeit of animal skins hiding his face, shaking a rattle and waving a spear. ${ }^{39}$ In London, he hired twenty London men and boys, outfitted them with Gallery costumes and artefacts, adorned them with theatrical make-up, and schooled them in performing war dances and war cries in "Tableaux Vivants Indiennes." Twice a week, on Monday and Thursday evenings, Catlin's troupe gave a carefully rehearsed performance of eleven war scenes or eight domestic interludes, enriching the static depictions of tribal life with war whoops, dances, and songs. Catlin himself appeared as a Crow chief, adding comment and context. He adopted a recent innovation in dramatic technique. Tableaux performances had only recently being introduced to New York theater in 1838, but had already become an established London fashion since Andrew Ducrow had made famous his poses plastiques équestres of the "frozen attitudes" of figures on horseback at Astley's Amphitheatre in 1828. ${ }^{40}$

Murray also persuaded his friend to indulge in extravagant costumed masquerades. Catlin enjoyed acting the Indian. As well as his regular, informal presentations in the Gallery, on at least one occasion, his impersonation was very deliberate. In February 1840, Murray, Catlin, and Catlin's nephew spent six hours rehearsing their performances, and then, dressed in Gallery costumes, copper body make-up and face- 
paint, went to the Caledonian Ball at Almack's Assembly Rooms in King Street, near St. James's Palace. The invitation-only dances held there were the most socially select in all London, with entry guarded by a small committee of snobbish aristocratic ladies determined to keep out the nouveaux riches, but through his aristocratic connections, Murray obtained tickets. ${ }^{41}$ Murray, disguised as a "Bois Brulé," a half-breed interpreter, explained to the surprised and startled guests in mixed French, German, and a hodgepodge of Indian dialects, the grunts and gestures of his companions. The "Sioux" scalpdance was the climax, when the painted "warriors" waving tomahawks exchanged scalp-locks for women's bracelets. The real drama of the evening was this confrontation of civilized and savage ways-of "silks and satins," "necklaces of diamonds" on "necks as fair as alabaster," and gold-braided uniforms, with beads, fur and feathers, and buffalo robes, of courtly etiquette and polite conversation with shrieking war cries and guttural sounds. At the most prestigious society ball, aristocratic ladies exchanged crafted jewellery and donned primitive trophies of human hair, and the measured steps and orchestral music of stately dances gave way to wild gesticulations and Catlin's war-drum beats. The jaunt ended in farce when the three perspired freely in the hothouse atmosphere, and as the greasepaint ran in streaks, Murray's identity was exposed, much to the amusement of his friends. ${ }^{42}$

A few weeks later, another small party, with Catlin's wife disguised as a "squaw," went to the Polish Ball at the Mansion House. This time, there was no unmasking, and Catlin noted with pride, they "passed off with everyone as real Indians," and were pleased to "enjoy the joke." ${ }^{43}$ Three years later, in late 1844, when the Iowa Indians were camped out in Vauxhall Gardens, Catlin once more donned costume, "fully arrayed" and "fully painted," to hoax visiting friends. However, afterwards he felt ashamed of pretending to two female acquaintances that he did not comprehend English. He had "trembled for fear" of being recognized, and trickery lost its appeal to him. Probably most embarrassing of all was his masquerade in the presence of a genuine Indian, Jim the Iowa, who was the closest confidant that Catlin had among the thirty-five Indians he exhibited in London, and who had been complicit in the deception. The "amusement" palled, Catlin wrote, "leaving me to regret my folly upon which I had thoughtlessly entered." ${ }^{44}$

For nineteenth-century Americans, dressing in feathers-what Rayna Green and Philip Deloria call "playing Indian"-was a very self-conscious cultural critique. In fraternal organizations like the New York Tammany Society or the Improved Order of Red Men, "Injun" rituals were transparent inventions that affirmed whiteness. Such representations embraced both savage freedom and civilized order. By incorporating the anarchy of the wild, players rejected a pale, transposed European identity and enervating over-refinement; by their disciplined organization and choreographed ceremonies, they eschewed anarchy. ${ }^{45}$ Mannered rebelliousness was also personally liberating. It was no coincidence that blacking up in exaggerated burnt-cork make-up was popular amateur as well as professional entertainment in the 1840s. Published manuals scripted performances impersonating "blacks" in dialect speeches. By imitating the uninhibited body language of the "Indian" savage or plantation "darkey," the white American escaped conventional restraints of polite etiquette and briefly assumed another persona. Middle-class theatricality was commonplace. The educated participated in or at least witnessed the spectacle. In September 1841, Nathaniel Hawthorne, with Emerson and Margaret Fuller, attended a fancy-dress picnic in a wood outside Boston. Amongst the costumed guests were Diana with her hunter's bow 
(whose arrow hit Hawthorne's hand), "a negro of the Jim Crow order," an Indian chief and an Indian squaw. In 1850, for an evening ball, Herman Melville outfitted himself as the legendary lustful Turk, complete with scimitar. ${ }^{46}$

In England, play-acting had rather different traditions. From Jane Austen's day, the elite enjoyed parlor games, charades, tableaux vivants and theatricals in private houses ${ }^{47}$ But racial masquerade had a rather different meaning. In England, there was no local experience of slavery or segregation. Genuine blacks were rare and AfricanAmerican fugitive slaves were the most popular antislavery lecturers. ${ }^{48}$ Indians too were exotic beings. Missing the immediate experience of brutal frontier warfare and the violent removal of tribes west of the Mississippi, the English cast Indianness in romantic shadows of forest gloom and doomed resistance. Catlin's nephew, physically the most impressive of the mock-Indians, wrote to his father in February 1841 that the costumed masquerades "take well" in London, "as it is something new and novel." Indeed, the sight of Burr Catlin bedecked as a Crow chief impressed the Gallery audience as "more strikingly" realistic, the London Morning Post commented, than all the authentic artefacts in the Hall. ${ }^{49}$

By the end of 1840 Catlin placed more importance on dramatic performance than on exhibiting his paintings as a means of generating income. During his extensive tour of provincial Britain, he left his Gallery behind in Manchester and Liverpool and relied on performance alone to convey an impression of North American Indian culture. For his lecture in Edinburgh on 6 April 1843, he appeared as a Crow chief with, a Scottish newspaper reported, "a huge hat encircled with a row of large war eagle feathers," fringed with scalps, and a bear's claw necklace, and holding a shield, a bow and a quiver of arrows. ${ }^{50}$

The chance appearance of three groups of North American Indians allowed Catlin to replace English actors with genuine "savages," and in the words of one English periodical, to add "spirit and reality" to the Gallery. In spring 1843, he hired nine Ojibwas, and after they left, fourteen Iowas in July 1844, who were in turn replaced by eleven Ojibwas in August 1845. None were untutored primitives plucked from forest or prairie. All were engaged in money-making tours organized by other showmen-the first Ojibwa party led by Arthur Rankin, the Iowas by George H. C. Melody, and the second group of Ojibwa under Maungwudaus. ${ }^{51}$

Catlin's use of the Iowas was for theatrical display: no mention was made of the Gallery collection of art or of his lectures detailing their cultural traits. The price of admission -one shilling-remained the same as for his past exhibitions, but this performance now lacked the cachet of the museum. In August 1844, the Indians appeared "encamped" in Lord's Cricket Ground, with four wigwams erected by the "squaws," and an outdoor stage on which they performed "war dances" and played lacrosse six afternoons a week from two to six, and in the evening from eight to ten in the Egyptian Hall. The Illustrated Evening News described it as ethnographic parade: The Iowas "are possessed of a splendid wardrobe, including every article of Indian attire, and travel with their own tents, camp equipage, canoes, and a beautiful collection of rifles, bows and arrows, and other implements manufactured by savage art, and used both in war and in the chase." 52 The Times reported large crowds: "Everybody appeared gratified by the sight." ${ }^{53}$ The inspiration may have been the visit of Cherokee chiefs in 1762. They had been on show at the Haymarket Theatre for a high admission charge but also appeared, like the Iowas, in Vauxhall Gardens to a much larger crowd of ten thousand..$^{54}$ 


\section{English Counterpoint: "Savage Views of Civilisation"}

The Iowas succeeded, Catlin wrote in his promotional pamphlet, in "transplanting an Indian village, into the heart of the civilized world," an English "prairie." ${ }_{55}$ In his publicity and in all his publications, Catlin made vivid comparisons between the wild men of the woods and sophisticated urban dwellers his essential point of reference. He portrayed the American Indian visitors as wise innocents who offered naïve but shrewd observations on English customs. With their "unenlightened eyes, they saw and correctly appreciated many things in London and Paris which the eyes of Londoners and Parisians scarcely see." ${ }^{56}$ Much of Catlin's Notes of Eight Years' Travels was filled with the comic escapades and unintentionally amusing remarks of the Ojibwas and Iowas. Jim and the Doctor-Catlin seldom used their Indian names-were shocked by the drunkenness, poverty, class differences, racial stigma, and religious hypocrisy conspicuous in the world's largest and wealthiest city. Catlin's humorous style muted the critical remarks and rendered them less offensive but the British newspapers and periodicals that commented on Catlin's Gallery and Catlin's books were sensitive to such observations.

Comparison between the white and "coloured" races was becoming a significant and controversial question in England in the early 1840s. Orthodox views based on the Bible or the Enlightenment had taught the fundamental unity of mankind. But the new science of comparative "ethnology" that measured cranial capacity in white and "coloured" skulls raised issues about evolution and progress. Perceived differences in brain size and intellectual capacity might be the product either of separate creations or accelerated versus stunted development over time. Perhaps the "coloured" had never been equal or were "debased" and "degraded" and had lapsed through idleness or intellectual inferiority and were destined to become extinct. The fulcrum of the debate shifted from uniformity and environmental determinants to accounting for disunity and degeneration. The leading scholar James Cowles Prichard engaged in comparative studies of language and religion and managed-with difficulty-to incorporate the new field research by Sir George Grey and others on the original inhabitants of Australia and Fiji that posed the question whether the aborigines had always been at a less advanced stage and always inferior in intellect. ${ }^{57}$

One of the liberal voices asserting the equal potential of non-white "races" was the distinguished physician Thomas Hodgkin. Since his essay "On the Promotion of Civilization" (1819) on the humanitarian obligation to less advanced peoples, the Quaker polymath had corresponded and exchanged ethnographic specimens with Prichard. Hodgkin founded the Aborigines' Protection Society in 1837 and the academic Ethnological Society of London in 1843. His particular concern was the impact of British imperial expansion on the native populations of Canada, South East Asia, Australasia, West and South Africa, and the fate of former slaves in the post-emancipation British Caribbean. ${ }^{58}$ Modern forces of "culture and refinement" that might promote uplift were "prostituted to purposes of cupidity and domination." "It surely behoves a British public," the Society declared, "to insist that the colonial rule of Britain be no longer such as to stain her name with the reproach of cruelty and injustice." 59

The fate of Indians in Canada was pressing. Hodgkin campaigned to limit the commercial operations of the Hudson's Bay Company that exchanged furs for whiskey, 
and lobbied British administrators for redress and government protection for the tribes. He had also played the major role in 1835 in raising funds to assist Francis Heshton-a-quet, chief of an Ojibwa group brought to England for show and left stranded, penniless and imprisoned. ${ }^{60} \mathrm{He}$ saw Catlin as a fellow spirit, even if he regarded religion as the essential agent of "civilization," and Catlin was indifferent, ambivalent or even hostile to such missionary endeavors. Hodgkin visited the Indian Gallery soon after it opened, and Catlin spoke at a meeting of the Aborigines' Protection Society in May 1840. In 1841 the Society also published, with an appropriate dedication, a reminiscence of Osceola, a "high-born Child of Nature" and one of the "untaught children of the wilderness." In the book Andrew Welch lauded the authenticity of Catlin's description of Osceola and on the poetic truth of his tableaux war-whoops in the Egyptian Hall. He concluded with a recommendation that the British government purchase the collection as a permanent museum for the Seminoles and "ample testimony" for this "noble class": "How much, then, does Mr. Catlin merit the gratitude of all civilized nations!"61

Hodgkin also gave the first private dinner for the Iowas in $1844 .^{62}$ Since Hodgkin continued to correspond with the Ojibwa Hesh-ton-a-quet after he returned to Canada, it is possible that he also had contact with the two Ojibwa groups that Catlin shepherded around London. Catlin produced etchings for the North American illustrations of the 1843 edition of Prichard's Natural History of Man. It was Hodgkin's Ethnological Society that endorsed Catlin's formal proposal for a global Museum of Mankind in $1851 .{ }^{63}$ Another link was Ralph Randolph Gurley, secretary of the American Colonization Society and sponsor of assisted emigration of African Americans to Africa. Hodgkin was an ardent supporter of assisted emigration to Liberia-as controversial in England as in America in humanitarian circles-and made Gurley a "foreign honorary member" of the Aborigines' Protection Society. For decades Gurley was Catlin's loyal friend and when he came to England in January 1841 soliciting funds, Catlin loaned him the use of the Egyptian Hall for three evenings' debate with the Anti-Slavery Society. ${ }^{64}$

Most English commentators responded favorably to Catlin's cultural critique, and concluded that Catlin's Indians on canvas and on stage were "dignified and agreeable," with "peculiar manners, and savage virtues," even a "Homeric" race fit for a classical saga. The Gallery exhibition proved, John Bull wrote, that Cooper's Indian was "pure fiction" and "poetic illusion." Chambers's Edinburgh Journal in 1848 was the most complimentary. In "Savage Views of Civilisation," it noted that Catlin's Indians had "innate goodness of character," and as outsiders, could reveal with "ingenuous eyes" and the "untutored mind" the shame of modern European life and the limited benefits that technology had brought to social welfare. Criticism of Andrew Jackson's Removal policy was general. "By an act of barbarism unexampled in history, [the] title of "Americans" has even been usurped by the progeny of Europe," the Quarterly Review declared. The Times agreed that driving natives from their lands and selling guns and drink doomed them to extinction. For, it noted gloomily, racial prejudice was the "impassable barrier which nature has erected between her white and her coloured children," and "very few systematic attempts" had ever been made at reform. ${ }^{65}$

However, for some, the savage virtues were limited to "childlike docility and manly daring." As many praised urban civilization with all its faults of poverty and privilege as saw merit in the noble savage doomed to disappear. Man in "natural freedom," the London Saturday Journal announced without ambiguity, was man "in humiliation and 
degradation," "a mere wild beast." ${ }^{66}$ The Ojibwa performance on stage was no better -"noisy and inexplicable shuffling," a "monotonous set of chants." The Times thought the Iowas the most wild: They were "grotesque," even "frightful," in manner and appearance, with incoherent grunts and gesticulations as uncouth as their animal-skin garments and paint-smeared bodies. Yet for patrons of primitivism who admired oddity and eccentricity however "disagreeable," their show promised to be a "huge treat." The Sunday Times noted gender differences among the Iowas. The men's dances were "singularly wild and interesting," while the placid, "contented air" of the women and children "are those of the Indians which we read of in Cooper's novels." 67

Charles Dickens sampled almost every kind of entertainment available in London. $\mathrm{He}$ wrote plays, performed in amateur dramatics, counted actors among his chosen friends, liked the circus, and enjoyed the music hall and working-class melodrama. But "Mr. Rankin's wild men" gave him no pleasure at all. Catlin's Indian was "a prodigious nuisance, and an enormous superstition," "a something highly desirable to be civilised off the face of the earth." Most of the tribes Dickens had seen during his visit to America in 1842 he considered debased. Here in London was further evidence of the "howling, whistling, clucking, stamping, jumping, tearing savage," "cruel, false, thievish, murderous." The red man was "addicted more or less to grease, entrails, and beastly customs; a wild animal with the questionable gift of boasting; a conceited, tiresome, bloodthirsty, monotonous humbug." 68

In a letter to his friend John Foster in October 1840, Dickens had listed some vague "Floating ideas" for his new periodical Household Words. One topic was "A history of Savages, showing the singular respects in which all savages are alike each other; and those in which civilised men, under circumstances of difficulty, soonest become like savages." It was not a theme that Dickens ever developed, but he detested sentimental attitudes to the primitive North American Indians or African Zulus exhibited. English humanitarians like Hodgkin were responsible for this travesty of hero worship. "It is not the miserable nature of the noble savage that is the new thing, it is the whimpering over him with maudlin admiration, and the affecting to regret him, and the drawing of any comparison of advantage between the blemishes of civilisation and his swinish life." Dickens was too conscious that London's "circumstances of difficulty" made the poor revert to the "savagery" evident to all in East End degradation, to sympathize with middle-class romanticism. For Dickens, Catlin's Indians were merely American Zulus, and an unwelcome distraction from social ills. ${ }^{69}$ The satirical magazine Punch went further. With mock gravitas, it joked that Catlin proposed a novel display of authentic savagery even more disgusting than the Iowas waving their grisly "real scalps" of human hair: Hottentots "girdled with sheep's intestines, and everything natural." Where, it mused, was James Fenimore Cooper's "majestic wild man" now? ${ }^{70}$

\section{The Sketch: Art Versus Theater}

One reason for the diverging views on savagery and civilization was the two very different styles of shows that Catlin presented. His original intention for the Indian Gallery was a comprehensive collection of art and artefacts that showed the range of Plains culture and would serve as a permanent resource and memorial. His evening lectures supplied essential explanatory information but at two shillings and sixpence each, or three for six shillings, and with his detailed Gallery catalogue priced at a 
shilling, these additional charges greatly limited admission. His philosophical musings about a Museum of Mankind or his talks to upper-class visitors in the Gallery or to scholarly and scientific bodies suited London's elite and Thomas Hodgkin. But as the London Saturday Journal noted, the Collection's appeal was to the "intellectual classes," and a year earlier, another journal observed that Catlin's public exhibition was an esoteric attraction-for "the intellectual sight-seer, and especially such as take interest in the rare science of ethnography." 71

Unfortunately, high culture alone could not meet Catlin's mounting expenses. He learned that Murray's theatrical gestures and story-telling to select aristocratic parties gave visitors a more immediate experience of life on the Plains than rows of canvas or shelves of peace pipes. And even the highbrow periodicals seldom mentioned the hundreds of engravings and lithographs in his books but recounted his autobiographical tales of courage and daring. Reviewers excerpted gory scenes of Mandan cruelty or thrilling buffalo hunts much more frequently than Catlin's more abstract thoughts on the noble savage or picturesque landscape. The responses affirmed his past experience of showmanship in the United States, with re-enactment as a necessary complement to painting. In his lectures he had a light touch, and English commentators praised his entertaining wit, his energy and enthusiasm, his colloquial Americanisms and "idiomatic raciness"-for instance the use of "whipped" as a synonym for defeated amused John Bull. ${ }^{72}$

Theater was immediately accessible. One shilling bought admission to the Indian Gallery in 1840 or to the outdoor exhibitions of the Iowas at Lord's Cricket Ground and Vauxhall Gardens in the late summer of 1844. Catlin understood that parading the Ojibwas and Iowas around the streets of Manchester and London was good publicity for the show. P.T. Barnum's outstanding success with his man-midget Tom Thumb was certainly a sharp lesson in the commercial realities of promotion. Barnum arrived in March 1844, sublet part of the Egyptian Hall from Catlin, but soon his one-shilling wonder proved far more popular with all classes than Catlin's Indians, and the darling of Murray's aristocratic clique. Catlin had hired Jac-o-Sot, a Sac Indian, "in splendid costume, with the shaved and crested head peculiar to that tribe, giving the war song, the death song and various dances"-but in Catlin's Indian Gallery, Thumb performed his array of Grecian Statues impersonations with Jac-o-Sot as the support act. ${ }^{73}$ As ultimate irony, Tom Thumb's renowned series of "living pictures," from Romulus to Napoleon, were all representations of civilized man, and a decided contrast to Catlin's mock-savages and real savages in "Tableaux Vivants Indiennes." The master showman had eclipsed the novice.

41 Catlin hoped for broad support for his venture. In England, liberals expected that what one periodical called "simple rational exhilarating pleasures" free from alcoholic excess or debilitating stupor would triumph and rich and poor would all enjoy leisure as true recreation and refreshment from labor. A visit to the British Museum or the National Gallery might displace the trivial sideshows of Bartholomew's Fair and combine instruction with amusement. ${ }^{74}$ However, the Indian Gallery's paintings and lectures proved less enticing than war-whoops and wigwams. 


\section{Catlin and the Wild West Show}

42 It is often said that Catlin's Indian Gallery inspired Buffalo Bill's Wild West and later shows. ${ }^{75}$ There are similarities. William Cody-Buffalo Bill-also placed particular emphasis in his European tour beginning in 1887 on "wild" Indians, with thrilling horsemanship and war-whoops, and an encampment that provided an extensive sideshow outside the main arena. Cody also made claims in his program to his historical accuracy-always presenting an "exhibition," never a show-and displayed certificates of authenticity. However, although Cody had been an army scout and professional buffalo hunter, he had also spent a decade in wintertime theatrical melodrama before his first themed western outdoor performance on July 41882 in Platte, Nebraska. The "Old Glory Blow-Out" was an Independence Day celebration of "cow-boy" skills of roping, riding, and shooting-with a buffalo chase and genuine Indians added on. Cody also cared little for tribal identities. The Sioux were sometimes required to dress as their traditional enemies, and even as Chinese Boxer rebels.

The 1880 s too was a very different era. In America, when frontier settlement was virtually complete, the Wild West celebrated "America's national entertainment" as the triumph of white "rough riders" over their valiant native foes. Catlin's aims differed fundamentally from Cody's. He saw himself not as a raconteur of America's civilizing glories but as the intermediary for "the noblest of savage nations," because "before many years the pure-blooded Indian will, no doubt, be extinct." 76 Only he, he claimed, had visited "almost every tribe east of the Rocky Mountains," had witnessed and depicted the authentic, primitive man, untouched, or almost untouched, by intercourse with whites-the "naked Savage" and the "finest models in Nature, unmasked," in forty-eight tribal varieties. ${ }^{77}$ He believed that he took exceptional care to record the peculiarities of every individual and every Plains group and identify them in his Catalogue, and was hugely pleased when visiting Indians recognised a portrait.

Catlin's benchmark remained the Indian galleries of his contemporaries-studio artists Charles Deas, Seth Eastman and John Mix Stanley, and fellow travelers in the field Karl Bodmer and Alfred Jacob Miller. He had to compete for patronage with their paintings or published portfolios, and with the publications of Henry Rowe Schoolcraft and Thomas L. McKenney. ${ }^{78}$ When his Indian Gallery failed to gain sufficient sponsorship in England, he dreamed of a fresh start in France and setting up a similar exhibition in the Louvre in 1845 with the patronage of Louis-Philippe and prominent intellectuals..$^{79}$ Even in England he never quite abandoned hope. In 1851 he submitted proposals to the Ethnological Society for a floating Museum of Mankind with his Collection as the centrepiece. He organized another show at the Great Exhibition, billed as "Promenade Lectures by Mr. CATLIN, with War-songs, War-whoops, \&c, at 2 in the day, and half-past 8 in the evening." ${ }^{80}$ Catlin's concept of the museum was a collection exhibited-and performed.

\section{Conclusion: Empathy with the "Red Devil"}

Catlin saw his mission in England as consciousness-raising, with performance as the key agent. If the "wild" Indians were to be saved from extinction, immediate action was imperative. His collection of art and artefacts preserved the outward form, his words described the cultures, and re-enactment conveyed the spirit. The educated elite 
represented by Charles Augustus Murray had access to the exhibition, the lectures, the portfolios and the books, but play-acting and tableaux vivants, particularly "living pictures" by real Indians and enlivened by the sound of war-whoops, reached the broadest public. Catlin had few doubts about pretense-guilt, perhaps, about dissimulation to friends when witnessed by Jim the Iowa-if his presentations conveyed poetic truth. When he justified the commercial aims of the three Indian troupes, he used a show-business analogy: their "making money" was "an enterprise as lawful and as unobjectionable, for aught I can see, at least, as that of an actor upon the boards of a foreign stage." ${ }^{\prime 1}$

Catlin wanted the English public to experience vicariously the lot of the "wild" Indian and understand the plight of the last remaining tribes untouched by civilization. In London he had links with defenders of aboriginal peoples and proponents of the new science of ethnology. Romantic fiction's natural man or graphic depictions of devilish savages were crass stereotypes that distorted perceptions. The forty-eight varieties of tribal cultures that he displayed in the Gallery revealed the truth, but drama provided a convenient vehicle to transcend the merely visual and stimulate interest and excitement. Even the truth was compromised. Catlin spoke none of the Indian languages, had no facilities to take extensive notes, and despite his remarkable energy, could only spend a limited time as a participant-observer with each group. His illustrations often included an eclectic mix of different tribal elements, and were, as Kathryn S. Hight labels them, "an alternative fantasy to a knight of the Round Table or a Roman or a Greek warrior." 82

The most appropriate analogy with another showman who combined art and artifice and blurred the boundaries between entertainment and instruction is not Cody, and certainly not Barnum whom Catlin despised, but the photographer Edward S. Curtis. Two generations later, Curtis envisaged a grand "North American Indian Project" to record the outward appearance and inward culture of the "vanishing" Indian in words and pictures. To gather funds for his highly ambitious enterprise, he embellished the facts by constructing a musical "picture-opera" for his transcontinental lecture tours, and scripted a "photoplay," a dramatized documentary film. ${ }^{83}$ Curtis and Catlin were not charlatans but both had a relaxed attitude to ethnographic detail. To understand the savage mind required empathy and psychological engagement with "their looks and their modes,"rather than literal accuracy.

\section{NOTES}

1. Brian W. Dippie, Catlin Among His Contemporaries: The Politics of Patronage (Lincoln: University of Nebraska Press, 1990).

2. George Catlin, Letters and Notes on the Manners, Customs, and Conditions of the North American Indians. Written during eight years' travel amongst the wildesttribes of Indians in North America in 1832 to 1839 (London, 1841, 2 vols.), I: 16. 
3. A Descriptive Catalogue of Catlin's Indian Collection; containing portraits, landscapes, costumes, etc., .. . (1840), in [George Catlin], Catlin's Notes of Eight Years' Travels and Residence in Europe, with his North American Indian Collection (London, 1848, 2 vols.), I: 249, 249-252.

4. Catlin's Notes, I, vii.

5. Rosemarie K. Bank, "Archiving Culture: Performance and American Museums in the Earlier Nineteenth Century," in Performing America: Cultural Nationalism in the American Theater, Jeffrey D. Mason and J. Ellen Gainor eds. (Ann Arbor: University of Michigan Press, 1999), 44-47. See also Bank, Theatre Culture in America, 1825-1860 (Cambridge: Cambridge University Press, 1997).

6. Catlin to Peter B. Porter, Peter B. Porter Papers, Buffalo and Erie County Historical Society, as quoted in Laurence M. Hauptman and George Hamell, "George Catlin: The Iroquois Origins of His Indian Portrait Gallery," New York History 84 (Spring 2003): 130. Dippie, Catlin, 15, and William H. Truettner, The Natural Man Observed: A Study of Catlin's Indian Gallery (Washington: Amon Carter Museum / National Collection of Fine Arts, Smithsonian Institution, 1979), 13, have very different transcriptions of the letter.

7. Truettner, Natural Man, 38.

8. The Diary of Philip Hone 1828-1851,Allan Nevins ed. (New York: Dodd, Mead, 1927), 454, quoted in Truettner, Natural Man, 37.

9. London Times, 3 February 1840,5 .

10. Catlin to Putnam Catlin, 31 August 1840, Catlin Papers, Missouri Historical Society, St. Louis, as quoted in Dippie, Catlin, 98-99.

11. Richard D. Altick, The Shows of London (Cambridge, MA: Harvard University Press, 1978); Pamela Pilbeam, Madame Tussaud and the History of Waxworks (London: Hambledon, 2003), chaps. 5 and 6.

12. J.S. Bratton, “English Ethiopians: British Audiences and Black-Face Acts, 1835-1865," Yearbook of English Studies 11 (1981): 127-42; George F. Rehin, "Blackface Street Minstrels in Victorian London and Its Resorts: Popular Culture and its Racial Connotations As Revealed in Polite Opinion," Journal of Popular Culture 15 (Summer 1981): 19-38.

13. Raymund Fitzsimons, Barnum in London (London: St. Martin's Press, 1969); A. H. Saxon, P. T. Barnum: The Legend and the Man (New York: Columbia University Press, 1989), chaps. 4-5.

14. Altick, Shows, 207.

15. See Max Berger, The British Traveller in America, 1835-1860 (New York: Columbia University Press, 1943); Christopher Mulvey, Anglo-American Landscapes: A Study of 19th Century AngloAmerican Travel Literature (Cambridge: Cambridge University Press, 1983), and Transatlantic Manners: Social Patterns in Nineteenth-Century Anglo-American Travel Literature (Cambridge: Cambridge University Press, 1990).

16. Wilbur Shepperson, British Emigration to North America: Projects and Opinions in the Early Victorian Period (Oxford: Oxford University Press, 1957), 257-259; Philip Taylor, Destination Magnet: European Emigration to the U.S.A. (New York: Harper and Row, 1971), chap. 5.

17. Calvin Colton, Manual for Emigrants to America (London, 1832), 128-129.

18. Blackwood'sEdinburgh Magazine 34 (1833): 285, quoted in David P. Crook, American Democracy in English Politics, 1815-1850 (Oxford: Oxford University Press, 1965), 116.

19. Frank Thistlethwaite, America and the Atlantic Community: Anglo-American Aspects, 1790-1850 (Philadelphia: University of Pennsylvania Press, 1959).

20. Illustrated London News 124 (September 14 1844): 167.

21. Willard Thorpe, "Cooper Beyond America," New York History 25 (October 1954): 522-539; Ray Allen Billington, Land of Savagery, Land of Promise: The European Image of the American Frontier in the Nineteenth Century (New York: Norton, 1981).

22. Observer 5 September 1824, quoted in Nils Erik Enkvist, Caricatures of Americans on the English Stage Prior to 1870 (Helsingfors: Ejnar Munksgaard Forlag, 1954), 41. See also Francis Hodge, 
Yankee Theatre: The Image of America on the Stage, 1825-1850 (Austin: University of Texas Press, 1964), chap. 4.

23. Larry Stephen Clifton, The Terrible Fitzball: The Melodramatist of the Macabre (Bowling Green, Ohio: Bowling Green University Press, 1993), 35.

24. Thomas Colley Grattan, "My Acquaintance with Edmund Kean," New Monthly Magazine 39 (1833): 146, quoted in Edward Ziter, The Orient on the Victorian Stage (Cambridge: Cambridge University Press, 2003), 59. See also 60-61, and the illustration of Kean in Huron costume, 62.

25. Jacky Bratton, "British Heroism and the Structure of Melodrama," in J.S. Bratton, et al., Acts of Supremacy: The British Empire and the Stage, 1790-1930 (Manchester: Manchester University Press, 1991), 18-61.

26. Colin G. Calloway, “The 'Wild Indian Savages' in Leeds," Thoresby Society Miscellany 16 (1977): 303-315; Carolyn T. Foreman, Indians Abroad, 1493-1938 (Norman, Okla.: University of Oklahoma Press, 1943); J.C.H. King, “A Century of Indian Shows: Canadian and United States Exhibitions in London 1825-1925," European Review of Native American Studies 5 (1991): 35-42.

27. Lester C. Olson, Emblems of American Community in the Revolutionary Era: A Study in Rhetorical Iconology (Washington: Smithsonian Institution Press, 1991), 77. See also Peter Thomas, The American Revolution (Cambridge: Cambridge University Press, 1986).

28. Tim Fulford, Romantic Indians: Native Americans, British Literature, and Transatlantic Culture 1756-1830 (Oxford: Oxford University Press, 2006), 3-40, 120-207. See also Troy O. Bickham, Savages within the Empire: Representations of American Indians in Eighteenth-Century Britain (Oxford: Oxford University Press, 2005); Kate Flint, The Transatlantic Indian, 1775-1930 (Princeton; Princeton University Press, forthcoming).

29. Fulford, Romantic Indians, 42-48, 82-89. See also Colin G. Calloway, White People, Indians, and Highlanders: Tribal People and Colonial Encounters in Scotland and America (Oxford: Oxford University Press, forthcoming).

30. Walter Scott, Introductions, and Notes and Illustrations, to the Novels, Tales, and Romances, of the Author of Waverley (Edinburgh: Whittaker \& Co., 1833, 3 vols.), II: 126.

31. Donald Macleod, Life of Walter Scott (New York: Charles Scribner, 1852), 144; The Journal of Sir Walter Scott,ed. W.E.K. Anderson (Oxford: Clarendon Press, 1972), 268, 629.

32. See especially Stephanie Pratt, American Indians in British Art, 1700-1840 (Norman: University of Oklahoma Press, 2005).

33. James Everett Seaver, A Narrative of the Life of Mrs. Mary Jemison (1824), xiii-xiv, quoted in June Namias, White Captives: Gender and Ethnicity on the American Frontier (Chapel Hill: University of North Carolina Press, 1993), 154; Fulford, 249-250, 236-254..

34. John Dunn Hunter, Memoirs of a Captivity Among the Indians of North America, From Childhood to The Age of Nineteen (London, 3rd. ed., 1824), 373.

35. C.A. Murray, Travels in North America during the years 1834, 1835 \& 1836, including a summer residence with the Pawnee Tribe of Indians and a visit to Cuba and the Azore Islands (London: Richard Bentley, 1839, 2 vols.). See H.E. Maxwell, "Murray, Sir Charles Augustus (1806-1895)," in Oxford Dictionary of National Biography, H.C.G. Matthew and Brian Harrison eds. (Oxford: Oxford University Press, 2004), online: http://www.oxforddnb.com/view/article/19596 (accessed April 17, 2008).

36. Catlin's Notes, I: 35.

37. Ibid., I, 36.

38. Ibid., I, 61-65. For the Museum of Mankind, see Dippie, Catlin, 114, 139-143, 168, 470-471 n. 83.

39. Paul Reddin, Wild West Shows (Urbana: University of Illinois Press, 1999), 13.

40. Catlin's Notes, I, 95; Truettner, Natural Man, 43; [Catlin], Lectures on the Manners and Customs of the North American Indians (London, [1841], broadside), online: www.archives.uc.edu/broadside (accessed May 2, 2001); Jack W. McCullough, Living Pictures on the New York Stage (Ann Arbor: UMI Research Press, 1983). 
41. James Grant, The Great Metropolis (London: 1837, 2 vols.) I, chap. 1; Jane Rendell, “Almack's Assembly Rooms-A Site of Sexual Pleasure," Journal of Architectural Education 55 (2002): 136-149.

42. Catlin's Notes, I : 69-76.

43. Ibid., I: 76-78.

44. Ibid., I: 87-89; II: 123-124.

45. Rayna Green, "The Tribe Called Wannabee: Playing Indian in America and Europe," Folklore 99 (1988): 30-55; Philip J. Deloria, Playing Indian (New Haven: Yale University Press, 1998), chaps. $1-2$.

46. Nathaniel Hawthorne, American Notebooks, ed. Claude Simpson (Columbus: Ohio State University Press, 1972), 202; Hershel Parker, Herman Melville: A Biography. Volume 1, 1819-1851 (Baltimore: Johns Hopkins University Press, 1996), 761-762. For growing acceptance of theatricality, see Karen Halttunen, Confidence Men and Painted Women: A Study of Middle-Class Culture in America, 1830-1870 (New Haven: Yale University Press, 1982).

47. Nina Auerbach, Private Theatricals: The Lives of the Victorians (Cambridge: Harvard University Press, 1990).

48. Bratton, "English," 135-142.

49. Marjorie Catlin Boehm, The Letters of George Catlin and His Family (Berkeley: University of California Press, 1966), 207; Catlin's Notes, I: 211.

50. The Scotsman 8 April 1843, quoted in Tom F. Cunningham, The Diamond's Ace: Scotland and the Native Americans (Edinburgh: Mainstream, 2001), 74.

51. Christopher Mulvey, "Among the Sag-a-noshes: Ojibwa and Iowa Indians with George Catlin in Europe, 1843-1848," in Indians and Europe: An Interdisciplinary Collection of Essays, Christian Feest ed. (Aachen: Edition Herodot, 1987), 253-75: Mulvey, "George Catlin in Europe," in George Catlin and his Indian Gallery, George Gurney and Therese Thau Heyman eds. (Washington: Smithsonian Institution, 2002), 63-91.

52. Illustrated London News 5 no. 117 (17 July 1844): 64; no. 121 (24 August 1844): 126, advertisement. See Reddin, Wild West Shows, 40-41.

53. Times 29 August 1844, 5.

54. John Oliphant, "The Cherokee Embassy to London, 1762," Journal of Imperial and Commonwealth History 27 (January 1999): 17-20.

55. Chambers's Edinburgh Journal n.s. 9 (June 24, 1848): 406; Unparalleled Exhibition. The Fourteen Ioway Indians and Their Interpreter, just arrived from the Upper Missouri, near the Rocky Mountains, North America (London, 1844), [2].

56. Ibid., II, 306-307. See Winona Stevenson, "Beggars, Chickabobbooags, and Prisons: Paxoche (Ioway) Views of English Society, 1844-45," American Indian Culture and Research Journal 17 (1993): 1-23.

57. George W. Stocking, Jr., Victorian Anthropology (New York: Free Press, 1987), 47-53, 74-109; Douglas A. Lorimer, Colour, Class and the Victorians: English Attitudes to the Negro in the MidNineteenth Century (Leicester: Leicester University Press, 1978), 131-146; Stephen Jay Gould,The Mismeasure of Man(New York: Norton, 1981); Reginald Horsman,Race and Manifest Destiny: The Origins of American Racial Anglo-Saxonism(Cambridge: Harvard University Press, 1981).

58. On Hodgkin and ethnology, see Amalie M. Kass and Edward H. Kass,Perfecting the World: The Life and Times of Dr. Thomas Hodgkin 1798-1866 (Boston: Harcourt Brace Jovanovich, 1988), 21-25; Ronald Rainger, "Philanthropy and Society in the 1830s: The British and Foreign Aborigines' Protection Society," Man 15 (December 1980): 702-717; Zoë Laidlaw, "Heathens, Slaves and Aborigines: Thomas Hodgkin's Critique of Missions and Anti-slavery," History Workshop Journal 64 (2007):133-161.

59. The Second Annual Report of the Aborigines Protection Society, May 21 ${ }^{\text {st }}, 1839$ (London: Society, 1839), 28-29.

60. Kass, Perfecting, 257-263. On British policy in the 1830s, see Mark Francis, “The 'Civilizing' of Indigenous People in Nineteenth-Century Canada," Journal of World History 9 (1998): 51-87. 
61. The Tablet May 16 1840; [Andrew Welch], A Narrative of the Early Days and Remembrances of Oceola Nikkanochee, Prince of Econchatti, a young Seminole Indian son of Econchatti-Mico (London: Hatchard and Son, 1841), [iv, iii], 196, 10, 23, 30, 31, 146, 195.

62. Catlin's Notes, I: 39; II: 29, 130.

63. James Prichard, Natural History of Man ... (Paris and London: H. Balliere, 1843); Sarah Walpole, “A Floating Museum of Mankind?" Anthropology Today 20 (2004): 24.

64. R. R. Gurley, Mission to England, in Behalf of the American Colonization Society (Washington: William W. Morrison, 1841), xi, 99-10; Dippie, 128-142.

65. "Catlin's Indian Gallery," John Bull (16 February 1840); "Savage Views of Civilisation," Chambers's Edinburgh Review 239 (June 1848): 406-410; “The Red Man," Quarterly Review 65 (March 1840): 209; Times October 14 1841, 3; Edinburgh Review 74 (January 1842): 421; Tait's Edinburgh Review 9 (February 1842): 117. See also Terry Jay Ellingson, The Myth of the Noble Savage (Berkeley: University of California Press, 2001).

66. "A Nut for the Ojibbeways," Dublin University Magazine 33 (March 1844): 348; “Catlin's Indian Gallery," London Saturday Journal 3 (February 1840): 97.

67. Times, 8 August 1844, 6; Catlin's advertisement, quoting press reviews, in Illustrated London News 5, no. 121 (24 August 1844): 126.

68. Paul Schlicke, Dickens and Popular Entertainment (London: Allen and Unwin, 1985); Charles Dickens, "The Noble Savage," Household Words 11 June 1853, in 'Gone Astray' and Other Papers from Household Words 1851-59,Michael Slater ed. (London: Dent, 1998), 143.

69. The Letters of Charles Dickens. Volume Five 1847-1849, eds. Graham Storey and K. J. Fielding (Oxford: Oxford University Press, 1981), 622; 'Gone Astray,' 143. See also Bernth Lindfors, “Charles Dickens and the Zulus," in Africans on Stage: Studies in Ethnological Show Business, Bernth Lindfors ed. (Bloomington: Indiana University Press, 1999), 62-80.

70. Punch, as quoted in Times, 5 September 1844, 3.

71. London Saturday Journal 3 (February 1842): 101; Mirror of Literature, Amusement, and Instruction 37 (April 1841): 252.

72. John Bull (16 February 1840).

73. London Morning Chronicle 21 March 1844, quoted in Reddin, 38.

74. "Amusements of the People," Illustrated Evening News 51 (22 April 1843):267. See Rachel Vorspan, "Rational Recreation" and the Law: The Transformation of Popular Urban Leisure in Victorian England," McGill Law Journal 45 (2000): 891-911; Peter Bailey, Leisure and Class in Victorian England: Rational Recreation and the Contest for Control, 1830-1885 (London: Routledge and Kegan Paul, 1978).

75. Reddin, 8-52. See also L.G. Moses, Wild West Shows and the Images of American Indians, 1883-1933 (Albuquerque: University of New Mexico Press, 1996). Joy S. Kasson, Buffalo Bill's Wild West: Celebrity, Memory, and Popular History (New York: Hill and Wang, 2000) is the most illuminating study.

76. A Short History and Description of the Ojibbeway Indians, [5], 7; Catlin's Notes, I, ix, 208.

77. Dippie, 86, 15.

78. See Dippie, 47-208.

79. See Sur le Sentier de la Découverte: Rencontres franco-indiennes du XVIe au XXe siècle, ed. Véronique Wiesinger (Paris: Réunion des musées nationaux, 1992); Claude Macherel and Daniel Fabre, "Du Far West au Louvre: Le musée indien de Georges Catlin," Gradhiva n.s. no. 3 (June 2006).

80. Official Catalogue of the Great Exhibition of the Works of Industry of All Nations, 1851, corrected ed. (London: W. Clowes \& Sons, 1851), 22 [advertising section], quoted in Bank, Theatre Culture, 180.

81. Catlin's Notes, I, vi-vii.

82. Kathryn S. Hight, “'Doomed to Perish': George Catlin's Depictions of the Mandan,” Art Journal 49 (Summer 1990): 123. 
83. Mick Gidley, Edward S. Curtis and the North American Indian, Incorporated (Cambridge: Cambridge University Press, 1998), 199-255.

\section{AUTHOR}

ROBERT M. LEWIS

University of Birmingham, UK 